\title{
HUBUNGAN KARAKTERISTIK IBU DENGAN SIKAP IBU HAMIL TRIMESTER III DALAM PEMILIHAN PENOLONG PERSALINAN DI WILAYAH KERJA PUSKESMAS PAI KABUPATEN BIMA
}

\author{
Robiatul Adawiyah $^{1}$, Nurul Ilmi ${ }^{2}$, Nismawardah ${ }^{3}$ \\ ${ }^{1,2,3)}$ Sekolah Tinggi Ilmu Kesehatan (STIKES) Mataram \\ Email: robiatuladawiyah42@gmail.com
}

\section{INTISARI}

Kematian ibu melahirkan masih merupakan masalah kesehatan di Indonesia. Salah satu faktor penyebabnya adalah pemilihan penolong persalinan. Pemilihan penolong persalinan dipengaruhi oleh karakteristik ibu yang meliputi umur, tingkat pendidikan, paritas dan pengetahuan. Penelitian ini bertujuan untuk menganalisa hubungan karakteristik ibu dengan sikap ibu hamil trimester III dalam pemilihan penolong persalinan di wilayah kerja Puskesmas Pai Kabupaten Bima.

Desain penelitian yang digunakan adalah studi korelasi dengan pendekatan cross sectional. Populasi dalam penelitian ini adalah semua ibu hamil trimester III di wilayah kerja Puskesmas Pai. Jumlah sampel sebanyak 38 orang yang diambil menggunakan teknik total sampling. Variabel independen yaitu karakteristik ibu yang meliputi umur, tingkat pendidikan, paritas dan pengetahuan sedangkan variabel dependen yaitu sikap ibu hamil dalam pemilihan penolong persalinan. Pengumpulan data kedua variabel mengggunakan kuesioner serta analisa data menggunakan Uji Spearman rank dan Chi Square dengan taraf signifikan 5\%.

Hasil penelitian diperoleh nilai p-value umur ibu $0,975>\alpha 0,05$ artinya $\mathrm{H}_{0}$ diterima dan $\mathrm{H}_{\mathrm{a}}$ ditolak, nilai $\mathrm{p}$-value pendidikan ibu $0,005<\alpha \quad 0,05$ artinya $\mathrm{H}_{0}$ ditolak dan $\mathrm{H}_{\mathrm{a}}$ diterima, nilai $X^{2}$ paritas ibu $0,180>\alpha 0,05$ artinya $\mathrm{H}_{0}$ diterima dan $\mathrm{H}_{\mathrm{a}}$ ditolak dan nilai p-value pengetahuan ibu $0,003<\alpha 0,05$ artinya $\mathrm{H}_{0}$ ditolak dan $\mathrm{H}_{\mathrm{a}}$ diterima.

Kesimpulan ada hubungan tingkat pendidikan dan pengetahuan ibu dengan sikap ibu hamil trimester III dalam pemilihan penolong persalinan di wilayah kerja Puskesmas Pai Kabupaten Bima. Dan tidak ada hubungan umur dan paritas ibu dengan sikap ibu hamil trimester III dalam pemilihan penolong persalinan di wilayah kerja Puskesmas Pai Kabupaten Bima. Diharapkan tenaga kesehatan untuk meningkatkan KIE tentang persalinan aman kepada ibu hamil terutama ibu dengan tingkat pendidikan rendah.

Kata Kunci: Karakteristik ibu, Sikap, Pemilihan penolong persalinan

\section{THE CORRELATION BETWEEN CHARACTERISTICS AND ATTITUDE OF TRIMESTER III MOTHERS IN SELECTING BIRTH ATTENDANT AT PAI HEALTHCARE CENTRE,BIMA}

\begin{abstract}
Maternal mortality is still a health problem in Indonesia. One of the factors of this problem is the choice Of birth attendant. Such choice is affected by mothers' characteristics which include age, education level, parity, and knowledge. This study
\end{abstract}


aims to analyze the correlation between characteristics and attitude of trimester III mothers in selecting birth attendant in Pai Healthcare Centre, Bima.

This study applies correlational design with cross-sectional approach. 38 trimester III mothers in Pai Healthcare Centre are chosen as the respondents through total sampling method. The independent variable is mothers' characteristics which includes age, education level, parity, and knowledge, while the dependent variable is mothers' attitude in choosing birth attendant. Data collection is done through questionnaire, which is then analyzed through Spearman rank test and chi square test with significance level of $5 \%$.

The findings show that $p$ value for mothers' age is 0,975 $>\alpha 0,05$ (Ho is accepted and $\mathrm{Ha}$ is rejected), $p$ value for mothers' education is 0,005 $<\alpha 0,05$ (Ho is rejected and Ha is accepted), $X^{2}$ value of mothers' parity is 0,180 > 0,05 (Ho is accepted and Ha is rejected), and lastly, the $p$ value of mothers' knowledge is 0,003 $<\alpha 0,05$ (Ho is rejected and $\mathrm{Ha}$ is accepted).

It can then be concluded that (1) there is a correlation between knowledge and level of education and attitude of trimester III mothers $n$ selecting birth attendant in Pai Healthcare Centre,Bima, and (2) there is no correlation between age and parity towards their attitude in chosing birth attendant. It is also suggested that health workers improve CIE about safe childbirth, especially for those with low level of education.

Keywords: mothers' characteristics, attitude, birth attendant selection

\section{PENDAHULUAN}

Dalam mewujudkan tujuan nasional seperti yang termaktub dalam Pembukaan Undang-Undang Dasar 1945 maka diselenggarakan pembangunan kesehatan nasional secara berencana, menyeluruh, terpadu,terarah dan berkesinambungan. Pembangunan kesehatan nasional adalah upaya untuk meningkatkan derajat kesehatan masyarakat yang setinggitingginya. Salah satu indikator derajat kesehatan masyarakat adalah angka kematian ibu (AKI). Makin tinggi AKI menunjukkan bahwa derajat kesehatan masyarakat dapat dikategorikan buruk dan belum berhasil dalam meningkatkan derajat kesehatan masyarakat (Kemenkes RI, 2013).

Kematian ibu melahirkan masih merupakan masalah utama dalam bidang kesehatan di Indonesia. Angka Kematian Ibu (AKI) di Indonesia masih tertinggi di Asia Tenggara mencapai 359/100.000 kelahiran hidup pada tahun 2012 kemudian AKI menujukkan penurunan menjadi 305 kematian ibu per 100.000 kelahiran hidup pada tahun 2014. Meskipun angka kematian ibu sudah mengalami penurunan namun belum memenuhi target MDGs 2015 sebesar 102/100.000 kelahiran hidup (Profil Kesehatan Indonesia, 2015).

Untuk menekan kematian ibu dalam proses persalinan, berbagai upaya telah dilakukan seperti program Jampersal (Jaminan Persalinan), program Pengembangan Desa Siaga dan Kementerian Kesehatan telah menerapkan kebijakan bahwa persalinan harus ditolong oleh tenaga kesehatan dan didorong untuk dilakukan di fasilitas pelayanan kesehatan. Untuk daerah dengan akses sulit, kebijakan Kementerian Kesehatan yaitu mengembangkan program Kemitraan Bidan dan Dukun serta Rumah Tunggu Kelahiran (Profil Kesehatan Indonesia, 2015). Penolong persalinan memberikan andil yang cukup besar pengaruhnya dalam menentukan status kesehatan ibu dan bayi karena sekitar $40 \%$ kelahiran di Indonesia dibantu oleh dukun bayi, 
keadaan ini umumnya terjadi di daerah perdesaan yang belum mampu dijangkau oleh pelayanan kesehatan secara memadai seperti Puskesmas, Pustu dan Polindes (Gita, 2010).

Di Provinsi NTB, cakupan persalinan ditolong tenaga kesehatan menunjukan peningkatan dari 92,96\% pada tahun 2013 menjadi 93,79\% pada tahun 2015 (Ditjen Kesehatan Masyarakat, Kemenkes RI, 2016). Meskipun telah menunjukan peningkatan cakupan persalinan ditolong tenaga kesehatan tetapi masih terdapat beberapa faktor yang menjadi hambatan yaitu sulitnya akses ibu hamil terhadap tempat pelayanan persalinan dan rendahnya dukungan keluarga terkait keputusan penetapan tempat persalinan di Fasyankes (Lakip Kemenkes, 2015).Berdasarkan data dari Dinas Kesehatan Kabupaten Bima menunjukkan bahwa pada tahun 2015 cakupan persalinan oleh tenaga kesehatan adalah 93,9\% dan telah mencapai target MDGs 90\%. Meskipun telah mencapai target tetapi masih terdapat beberapa Puskesmas di Kabupaten Bima yang belum memenuhi capaian target yaitu Puskesmas Sape dengan cakupan persalinan oleh tenaga kesehatan 88,5\%, Puskesmas Bolo dengan cakupan persalinan oleh tenaga kesehatan 89,0\%, dan Puskesmas Pai Berdasarkan data dari Dinas Kesehatan Kabupaten Bima menunjukkan bahwa pada tahun 2015 cakupan persalinan oleh tenaga kesehatan adalah 93,9\% dan telah mencapai target MDGs 90\%. Meskipun telah mencapai target tetapi masih terdapat beberapa Puskesmas di Kabupaten Bima yang belum memenuhi capaian target yaitu Puskesmas Sape dengan cakupan persalinan oleh tenaga kesehatan 88,5\%, Puskesmas Bolo dengan cakupan persalinan oleh tenaga kesehatan 89,0\%, dan Puskesmas Pai.

Penelitian ini dilakukan untuk mengetahui hubungan karakteristik ibu dengan sikap ibu hamil trimester III dalam pemilihan penolong persalinan di wilayah kerja Puskesmas Pai Kabupaten Bima.

\section{BAHAN DAN METODE}

Desain yang digunakan dalam penelitian ini adalah metode kuantitatif dengan desain studi analitik yaitu penelitian yang dilakukan terhadap dua variabel yang dihubungkan yaitu hubungan antara karakteristik ibu dengan sikap ibu hamil trimester III dalam pemilihan penolong persalinan. Pendekatan yang digunakan dalam penelitian ini adalah cross sectional dimana pada penelitian ini pengukuran atau pengamatan dilakukan pada saat yang bersamaan (sekali waktu) antara variabel independen dan variabel dependen (Nursalam, 2011).

Pengambilan data langsung dari rumah responden yang dijadikan sampel dimana sebelumnya peneliti mengutarakan tujuan penelitian dan meminta persetujuan klien menjadi responden melalui informed consent. Pengumpulan data dilakukan dengan membagikan lembar kuesioner pada responden untuk diisi dimana sebelumnya peneliti menjelaskan terlebih dahulu cara pengisian kuesioner tersebut.

Dalam penelitian ini Instrumen yang digunakan dalam penelitian ini adalah kuesioner. Kuesioner yang digunakan dalam penelitian ini adalah jenis kuesioner langsung yang tertutup karena responden hanya tinggal memberikan jawaban pada salah satu jawaban yang dianggap benar dari pilihan jawaban yang telah disediakan.

Untuk mengumpulkan data pada variable karakteristik ibu digunakan kuesioner. Karakteristik ibu meliputi umur, tingkat pendidikan, pengetahuan dan paritas. Untuk mendapatkan data pengetahuan ibu hamil trimester III tentang pemilihan penolong persalinan digunakan kuesioner dengan 10 pertanyaan yang mencakup 3 tingkatan pengetahuan yaitu tahu, 
memahami dan aplikasi dengan bentuk pertanyaan multiple choice item dimana telah disediakan pilihan jawaban. Jika responden memilih jawaban yang benar maka diberi skor 1 dan jika responden memilih jawaban yang salah maka diberi skor 0 .

\section{HASIL DAN PEMBAHASAN}

Hasil observasi ibu hamil trimester III pada setiap dusun di wilayah kerja Puskesmas Pai, sebagai berikut:

Tabel 4.1 Distribusi Ibu Hamil Trimester III Pada Setiap Dusun di Wilayah Kerja Puskesmas Pai

\begin{tabular}{|c|l|c|c|}
\hline No & Dusun & Jumlah & Persentase \\
\hline 1 & Kalo & 2 & $5.3 \%$ \\
\hline 2 & Pai & 5 & $13.2 \%$ \\
\hline 3 & Pai Dalam & 5 & $13.2 \%$ \\
\hline 4 & Nanga Na'e & 4 & $10.5 \%$ \\
\hline 5 & Wiya & 9 & $23.6 \%$ \\
\hline 6 & Tengge & 6 & $15.8 \%$ \\
\hline 7 & Oi Tui & 6 & $15.8 \%$ \\
\hline 8 & Oi Tui2 & 1 & $2,6 \%$ \\
\hline & Total & 38 & $100 \%$ \\
\hline
\end{tabular}

Tabel 4.2 Distribusi responden berdasarkan umur,pendidikan,paritas dan pengetahuan tentang pemilihan penolong persalinan di wilayah kerja Puskesmas Pai

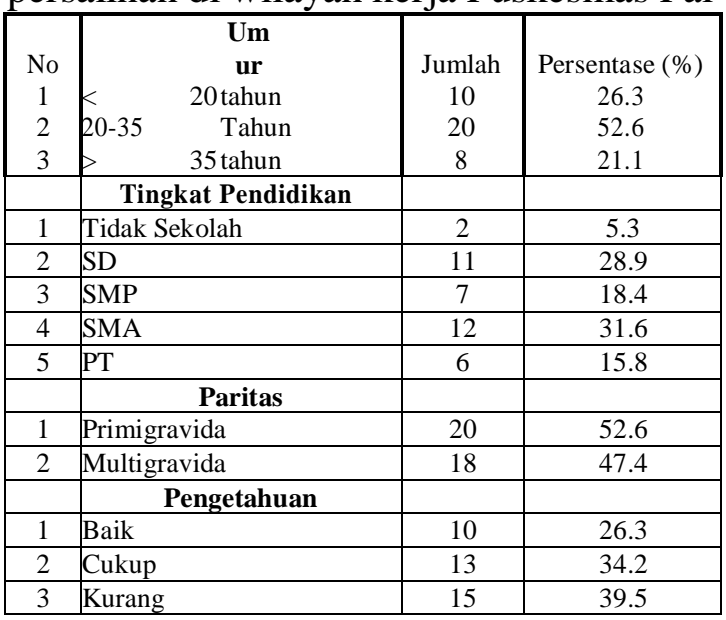

Tabel 4.3 Distribusi responden berdasarkan sikap tentang pemilihan penolong persalinan di wilayah kerja Puskesmas Pai

\begin{tabular}{|c|l|c|c|}
\hline No & \multicolumn{1}{|c|}{ Sikap } & Jumlah & Persentase (\%) \\
\hline 1 & Positif & 21 & 55.3 \\
\hline 2 & Negative & 17 & 44.7 \\
\hline
\end{tabular}

\begin{tabular}{|l|l|l|l|}
\hline Total & 38 & 100 \\
\hline
\end{tabular}

Tabel 4.4 Analisa Hubungan Umur, tingkat pendidikan, paritas dan pengetahuan tentang pemilihan penolong persalinan dengan Sikap Ibu Hamil trimester III dalam pemilihan penolong persalinan di wilayah kerja Puskesmas Pai

\begin{tabular}{|c|c|c|c|c|c|c|c|}
\hline \multirow[t]{3}{*}{ Umur } & \multicolumn{4}{|c|}{$\begin{array}{l}\text { Sikap Dalam Pemilihan } \\
\text { Penolong Persalinan }\end{array}$} & \multirow{2}{*}{\multicolumn{2}{|c|}{ Total }} & $\begin{array}{l}\text { p- } \\
\text { values }\end{array}$ \\
\hline & \multicolumn{2}{|c|}{ Negatif } & \multicolumn{2}{|c|}{ Positif } & & & \\
\hline & $\mathrm{F}$ & $\%$ & $\mathrm{f}$ & $\%$ & & & \\
\hline$<20$ thn & 4 & 10.5 & 6 & 15.8 & 10 & 26.3 & \multirow[t]{3}{*}{0.975} \\
\hline $20-35$ & 10 & 26.3 & 10 & 26.3 & 20 & 52.6 & \\
\hline$>35$ thn & 3 & 7.9 & 5 & 13.2 & 8 & 21.1 & \\
\hline \multicolumn{8}{|l|}{$\begin{array}{l}\text { Tingkat } \\
\text { pendidikan }\end{array}$} \\
\hline Tidak sekolah & 2 & 5.3 & 0 & 0 & 2 & 5.3 & \multirow[t]{5}{*}{0.005} \\
\hline SD & 7 & 18.4 & 4 & 10.5 & 11 & 28.9 & \\
\hline SMP & 3 & 7.9 & 4 & 10.5 & 7 & 18.4 & \\
\hline SMA & 5 & 13.2 & 7 & 18.4 & 12 & 31.6 & \\
\hline PT & 0 & 0 & 6 & 15.8 & 6 & 15.8 & \\
\hline \multicolumn{8}{|l|}{ Paritas } \\
\hline Primigravida & 11 & 28.9 & 9 & 23.7 & 20 & 52.6 & \multirow[t]{2}{*}{0.180} \\
\hline Multigravida & 6 & 15.8 & 12 & 31.6 & 18 & 47.4 & \\
\hline \multicolumn{8}{|l|}{ Pengetahuan } \\
\hline Kurang & 11 & 28.9 & 4 & 10.5 & 15 & 39.5 & \multirow[t]{3}{*}{0,003} \\
\hline Cukup & 3 & 7.9 & 10 & 26.3 & 13 & 34.2 & \\
\hline Baik & 3 & 7.9 & 7 & 18.4 & 10 & 26.3 & \\
\hline
\end{tabular}

\section{PEMBAHASAN}

Hasil penelitian menunjukkan bahwa ibu hamil trimester III yang berumur $<20$ tahun sebagian besar mempunyai sikap positif dalam pemilihan penolong persalinan yakni sebanyak 6 responden $(15,8 \%)$. Kemudian sebagian dari ibu hamil trimester III berumur 20-35 tahun yang mempunyai sikap negatif dalam pemilihan penolong persalinan yakni sebanyak 10 responden $(26,3 \%)$. Sedangkan ibu hamil trimester III yang berumur $>35$ tahun sebagian besar mempunyai sikap positif yakni sebanyak 5 responden $(13,2 \%)$. Berdasarkan hasil analisa statistik uji korelasi spearman rank menunjukkan nilai probabilitas $\mathrm{p}=0,975>\alpha(0,05)$ artinya tidak ada hubungan yang signifikan antara umur dengan sikap ibu hamil trimester III dalam pemilihan penolong persalinan di wilayah kerja Puskesmas Pai Kabupaten Bima.Hasil penelitian sesuai dengan pernyataan Naek L.Tobing (2010) yang 
mengemukakan bahwa ibu hamil berumur $<20$ tahun dan > 35 tahun merupakan kehamilan beresiko tinggi. Jika ibu hamil menyadari resiko dalam kehamilan dan persalinan yang akan muncul pada usia tersebut maka ia akan lebih berhati-hati dalam memilih tenaga penolong persalinan tingkat pendidikan ibu hamil trimester III di wilayah kerja Puskesmas Pai diketahui bahwa ibu hamil dengan pendidikan SD sebanyak 7 responden $(18,4 \%)$ rata-rata memiliki sikap yang negatif dalam pemilihan penolong persalinan yang artinya ibu hamil lebih cenderung beranggapan untuk memilih non tenaga kesehatan sebagai penolong persalinan. Sedangkan ibu hamil dengan dengan latar belakang pendidikan SMA sebagian besar memiliki sikap positif dalam pemilihan penolong persalinan yakni sebanyak 7 responden $(18,4 \%)$. Berdasarkan hasil uji analisis Rank Spearman diperoleh nilai p-value 0,005 sehingga nilai $p$-value lebih kecil daripada $\alpha(0,05)$ atau $0,005<0,05$ artinya ada hubungan yang signifikan antara tingkat pendidikan dengan sikap ibu hamil trimester III dalam pemilihan penolong persalinan di wilayah kerja Puskesmas Pai Kabupaten Bima.

Pendidikan merupakan hal yang sangat penting bagi seseorang dimana pendidikan formal akan membekali seseorang dengan dasar-dasar pengetahuan, teori dan logika, kemampuan analisis serta pengembangan kepribadian. Dalam hubungannya dengan pelayanan kesehatan, bila seseorang mempunyai pengetahuan dan pendidikan yang tinggi, maka akan mempercepat penerimaan pesan-pesan, informasi yang disampaikan tentang manfaat dan jenis pelayanan yang disediakan (Notoatmodjo, 2007). Pendidikan seseorang sangat berpengaruh terhadap perilaku individu dalam mengambil setiap keputusan dan sikapnya yang selalu berpedoman pada apa yang mereka dapatkan melalui proses belajar dan pengalaman yang diterimanya.
Ibu yang berpendidikan akan lebih terbuka terhadap ide-ide baru dan perubahan untuk mendapatkan pelayanan kesehatan yang proporsional karena manfaat pelayanan kesehatan akan mereka sadari sepenuhnya (Padila, 2014).

Lia Amalia (2012) menyatakan bahwa tingkat pendidikan rendah lebih cenderung untuk memanfaatkan persalinan oleh dukun bayi sedangkan responden dengan tingkat pendidikan yang lebih tinggi memanfaatkan persalinan oleh tenaga kesehatan. Pernyataan serupa dikemukakan Wulansari (2010), berdasarkan hasil penelitiannya menunjukkan bahwa semakin tinggi tingkat pendidikan maka variasi tempat persalinan lebih banyak. Tingkat pendidikan responden juga mempengaruhi besarnya informasi yang diserap oleh responden dalam hal kesehatan termasuk penolong persalinan yang baik dan benar, sehingga akan mempengaruhi keputusan responden dalam memilih penolong persalinan. Hasil penelitian, menunjukan bahwa sebagian besar responden yang mempunyai pengetahuan kurang tentang pemilihan penolong persalinan cenderung bersikap negatif yakni sebanyak 11 responden $(28,9 \%)$. Kemudian responden yang mempunyai pengetahuan cukup sebagian besar mempunyai sikap positif yakni sebanyak 10 responden (26,3\%). Sedangkan responden yang mempunyai pengetahuan baik sebagian besar mempunyai sikap positif yakni sebanyak 7 responden $(18,4 \%)$. Berdasarkan hasil analisa statistik uji korelasi spearman rank menunjukkan nilai probabilitas $\mathrm{p}=0,003<\alpha=0,05$. Dengan demikian maka kesimpulan yang diambil adalah menolak Ho dan menerima $\mathrm{Ha}$, artinya ada hubungan yang signifikan antara pengetahuan dengan sikap ibu hamil trimester III dalam pemilihan penolong persalinan di wilayah kerja Puskesmas Pai Kabupaten Bima. Pengetahuan mempunyai peran yang sangat penting 
dalam pembentukan sikap karena salah satu komponen yang memegang peranan penting dalam pembentukan sikap diantaranya adalah pengetahuan. Oleh karena itu pengetahuan sangat menentukan orang itu bersikap positif atau negatif, sesuai dengan Teori Anwar (2013) menyebutkan bahwa pengetahuan yaitu komponen kognitif merupakan respresentasi uji yang dipercayai seseorang mengenai apa yang berlaku, sekali kepercayaan itu sudah terbentuk, maka akan menjadi dasar pengetahuan seseorang mengenai apa yang dia harapkan sehingga pengetahuan sangat menentukan orang untuk bersikap positif atau negatif.

Wawan (2010) juga mengemukakan pendapat yang serupa bahwa pengetahuan merupakan faktor penting dalam menentukan sikap seseorang karena pengetahuan dapat menimbulkan perubahan persepsi dan kebiasaan masyarakat. Pengetahuan yang meningkat dapat merubah persepsi masyarakat tentang penyakit. Meningkatnya pengetahuan juga dapat mengubah sikap masyarakat dari yang negatif menjadi positif, selain itu pengetahuan juga membentuk kepercayaan.

Dengan demikian, semakin tinggi pengetahuan seseorang tentang penolong persalinan maka akan lebih cenderung bersikap positif terhadap penolong persalinan dan begitupun sebaliknya. Namun perlu ditekankan lagi, masih banyak faktor lainnya yang mempengaruhi sikap yang artinya tidak mutlak seseorang berpengetahuan baik memiliki sikap positif dan sebaliknya tidak mutlak seorang berpengetahuan kurang memiliki sikap negatif.

\section{KESIMPULAN}

1. Tidak ada hubungan yang signifikan antara umur dengan sikap ibu hamil trimester III dalam pemilihan penolong persalinan di wilayah kerja Puskesmas Pai Kabupaten Bima, hal ini berdasarkan hasil analisa statistik uji korelasi spearman rank menunjukkan nilai $p$-value lebih besar daripada $\alpha$ $(0,05)$ atau $0,975>0,05$.

2. Ada hubungan yang signifikan antara tingkat pendidikan dengan sikap ibu hamil trimester III dalam pemilihan penolong persalinan di wilayah kerja Puskesmas Pai Kabupaten Bima, hal ini berdasarkan hasil analisa statistik uji korelasi spearman rank menunjukkan nilai $p$-value lebih kecil daripada $\alpha$ $(0,05)$ atau $0,005<0,05$.

3. Tidak ada hubungan yang signifikan antara paritas ibu dengan sikap ibu hamil trimester III dalam pemilihan penolong persalinan di wilayah kerja Puskesmas Pai Kabupaten Bima, hal ini berdasarkan hasil analisa statistik uji korelasi chi-square menunjukkan dengan nilai $X^{2}$ lebih besar daripada $\alpha$ $(0,05)$ atau $0,180>0,05$.

4. Ada hubungan yang signifikan antara pengetahuan dengan sikap ibu hamil trimester III dalam pemilihan penolong persalinan di wilayah kerja Puskesmas Pai Kabupaten Bima, hal ini berdasarkan hasil analisa statistik uji korelasi spearman rank menunjukkan nilai $p$-value lebih kecil daripada $\alpha$ $(0,05)$ atau $0,003<0,05$.

\section{SARAN}

\section{Bagi Ibu Hamil}

Ibu hamil perlu meningkatkan pengetahuannya tentang pentingnya pertolongan persalinan oleh tenaga kesehatan sehingga pada waktu melahirkan memilih tenaga kesehatan sebagai penolong persalinan.

\section{Bagi Puskesmas}

Dalam rangka meningkatkan status kesehatan ibu dan anak di wilayah kerja Puskesmas Pai, tenaga kesehatan perlu meningkatkan kerja sama lintas sektoral dengan aparatur desa, tokoh masyarakat, tokoh agama, 
kader, dan dukun terlatih maupun dukun tidak terlatih dengan meningkatkan komunikasi, informasi dan edukasi (KIE) kepada masyarakat terutama ibu hamil secara berkesinambungan seperti penyuluhan pada setiap kali posyandu, acara-acara sosial, pengajian.

\section{Bagi Instansi Pendidikan}

Penelitian ini dapat di jadikan acuan dan referensi untuk pembelajaran serta dapat dimanfaatkan untuk penelitian selanjutnya.

\section{Bagi Peneliti}

Bagi peneliti selanjutnya agar dapat meneliti tentang faktor lainnya yang mempengaruhi pemilihan penolong persalinan seperti faktor dukungan suami dan sosial budaya.

\section{DAFTAR PUSTAKA}

Amalia, Lia. 2012. Faktor-Faktor Yang Mempengaruhi Ibu Dalam Pemilihan Penolong Persalinan.

Azrul, Azwar. 2006. Strategi Percepatan Penurunan Kematian Ibu Melalui
Peningkatan Kualitas Pelayanan, Advocasi Workshop Strategi dan Kegiatan yang Berhasil dalam Program Safe Motherhood. Depkes RI : Jakarta.

Bandiyah, Siti. 2009. Kehamilan, Persalinan \& Gangguan

Kehamilan. Yogyakarta : Nuha Medika.

Bobak. 2005. Buku Ajar Keperawatan Maternitas edisi 4.

Jakarta : EGC. Depdiknas. 2007. Program Wajib Belajar 6 Tahun. Depdiknas. Jakarta.

Depkes RI. 2005. Standar Pelayanan Kebidanan. Jakarta : Depkes.

Dinas Kesehatan Kabupaten Bima. 2015. Profil Kesehatan Kabupaten Bima Tahun 2015. Kabupaten Bima.

Gita, Setyawati. 2010. Model Sosial dan Pemilihan Dukun Dalam Peroses Persalinan: Apakah Relevan?. Makara. Kesehatan. Vol. 14. No. 1 Juni 2010 (11-16).

Hasibuan, Abdul Wahab. 2012. Gambaran Karakteristik Ibu Dalam Pemanfaatan Penolong Persalinan Di Wilayah Kerja Puskesmas Gunung Baringin Kecamatan Panyabungan Timur Kabupaten Mandailing Natal.

Hemiati, Sri. 2007. Enam Puluh Sembilan Juta Ibu Hamil Belum Terlayani Tenaga Kesehatan Terlatih: diakses dari http://www.Kapanlagi.com. 5 September, 2016.

Hidayat, Alimul Aziz. 2007. Riset Keperawatan Dan Teknik Penulisan Ilmiah. Jakarta : Salemba Medika.

Ihsan, Fuad. 2007. Dasar-dasar Kependidikan. Jakarta: PT Asdi Mahasatya.

Ika Mardiatul Ulfa, dkk. 2015. Hubungan Pengetahuan Dengan Sikap Ibu Hamil Trimester III Tentang Pemilihan Penolong Persalinan Di Puskesmas Beruntung Raya Banjarmasin.

Juariah. 2009. Antara Bidan Dan Dukun. Majalah Bidan Volume XIII. 
Jakarta. Juliwanto, Elvistron. 2009. Faktor-faktor Yang Mempengaruhi Keputusan Memilih Penolong Persalinan Pada Ibu Hamil Di Kecamatan Babul Rahmah Kabupaten Aceh Tenggara Tahun 2008. Universitas Sumatera Utara.

Kementerian Kesehatan RI. 2011. Profil Kesehatan Indonesia 2010. Jakarta. 2013. Balitbang Kemenkes RI. 2013. Riset Kesehatan Dasar; RISKESDAS. Jakarta: Balitbang Kemenkes RI. 2015. Lakip Kemenkes 2015. Jakarta.

Koentjaraningrat. 2007. Manusia dan Kebudayaan di Indonesia. Jakarta : Djambatan.

Kurnia, Nova. 2009. Menghindari Gangguan Saat Melahirkan \& Panduan Lengkap Mengurut Bayi. Yogjakarta : Panji Pustaka.

Lili Tiara Furi, dkk. 2013. Faktor Yang Mempengaruhi Ibu Bersalin Pada Dukun Bayi Dengan Pendekatan Who Di Desa Brongkal Kecamatan Pagelaran Kabupaten Malang.

Machfoedz, Irham. 2007. Statistika Deskriptif : Bidang Kesehatan, Keperawatan dan Kebidanan (Bio Statistik). Yogyakarta : Fitramaya.

Manuaba, IBG. 2010. Ilmu Kebidanan, penyakit Kandungan dan KB untuk Pendidikan Bidan Edisi 2. Jakarta : EGC.

Mochtar, Rustam. 2007. Sinopsis Obstetri:Obstetri Fisiologi, Obstetri Patologi. Edisi III. Jakarta: EGC.

Naek, L.Tobing. 2010. Kesehatan Maternal Dan Keluarga Berencana. Jakarta : EGC.

Notoatmodjo, Soekidjo. 2007. Ilmu Kesehatan Masyarakat PrinsipPrinsip Dasar. Jakarta : PT Rineka Cipta.

Nugroho, dkk. 2014. Buku Ajar Asuhan

Kebidanan 1: Kehamilan. Jakarta: Yayasan Bina Pustaka. Nursalam\&Efendi, Ferry. 2008.
Pendidikan Dalam Keperawatan. Jakarta : Salemba Medika

Nursalam. 2008. Konsep Dan Penerapan Metodologi Penelitian Ilmu keperawatan. Edisi 2. Jakarta : Salemba Medika Profil Kesehatan RI. 2015. Profil Kesehatan 2015. Badan Penelitian dan Pengembangan Kementerian Kesehatan RI. Jakarta.

Purwanto, M. Ngalim.2006. Psikologi Pendidikan. Bandung: Remaja Rosdakarya

Ridwan, Amirudin. 2006. Faktor-faktor yang berhubungan dengan pemilihan tenaga penolong persalinan oleh ibu bersalin di wilayah kerja Puskesmas Borong Kompleks Kabupaten Sinjai tahun 2006.

Riwidikdo, Handoko. 2012. Statistik Kesehatan. Yogyakarta: Nuha Madika.

Sugiyono. 2008. Metode Penelitian Kuantitatif Kualitatif dan $R \& D$. Bandung: Alfabeta.

Suharsimi, Arikunto. 2007. Prosedur Penelitian Suatu Pendektan Praktek. Yogyakarta : Rineka Cipta.

Sulystiawati, Ari. 2009. Asuhan Kebidanan Pada Masa Kehamilan. Yogyakarta : CV. Andi Offset.

Sumiati, Suriati, Iwan, M., \& Ramdan. 2012 Pemanfataan Posyandu Lansia Di Wiilayah Kerja Puskesmas Wonorejo Samarinda, 6-10

Supartini. 2004. Pelayanan Kesehatan Bagi Ibu Hamil.Jakarta : EGC.

Suprapto. 2007. Komplikasi Persalinan dan Risiko Kematian Ibu. EGC : Jakarta

Suryabudhi, Maria. 2003. Cara Merawat Bayi dan Anak-anak. Bandung: Alfabeta

Sutanto. 2002. Faktor-Faktor Yang Berhubungan Dengan Pemilihan Tenaga Penolong Persalinan. Tesis UI. Jakarta 
Syafruddin. 2009. Organisasi dan Manajemen Pelayanan Kesehatan dalam Kebidanan. Jakarta: Trans Info Media.

Varney, Helen. 2007. Buku Ajar Asuhan Kebidanan Edisi4. Jakarta : EGC.

VirBala, Anggarwal. 2008. Pengertian Media Massa, http://www.mediamassa.com.

(DiaksesAgustus 2016).

Wawan, A\&Dewi, M. 2010. Teori dan Pengukuran Pengetahuan, Sikap dan Perilaku Manusia. Yogyakarta : Nuha Medika.

Widayatun. 2012. Program penempatan bidan di I desa di Indonesia dan Tingkat Pemanfaatan Pelayanan Kesehatan Ibu dan Anak. Buletin Pengkajian Masalah Kependudukan dan Pembangunan X (1-3) 1999.

Wikjhosastro, Hanifa. 2009. Ilmu Kebidanan. Jakarta : PT. Bina Pustaka.

Wulansari, Triani. 2010. Analisis spasial pemilihan tempat pertolongan Persalinan.

Yenita, Sri. 2011. Faktor Determinan Prmilihan Penolong Persalinan di Wilayah Kerja Puskesmas Desa Baru Kabupaten Pasaman Barat Tahun 2011. Tesis, Program Pasca Sarjana UNAND. 